\title{
Determinants of Unemployment in Bangladesh: A Case Study
}

\author{
Mohammad Shafiur Rahman Chowdhury \\ Lecturer, Department of Economics \\ Jatiya Kabi Kazi Nazrul Islam University \\ Trishal, Mymensingh, Bangladesh. \\ Contact: +8801813360391, Email: shohag_eco51@yahoo.com \\ Md. Tanjil Hossain \\ Assistant Professor, Department of Economics \\ Jatiya Kabi Kazi Nazrul Islam University \\ Trishal, Mymensingh, Bangladesh. \\ Contact: +8801677391132, Email: tanjilhossain@yahoo.com
}

\begin{abstract}
:
A very important issue that plays a crucial role in development of the economies is the underutilization of its human capital i.e. unemployment. This paper investigates macroeconomic determinants of unemployment rate in Bangladesh economy for the period of 2000-2011 using Simple Single Equation Linear Regression Model (SELRM). The variables selected for the study are Unemployment rate, GDP growth rate, Exchange rate and Inflation rate (CPI based). The results of regression analysis showed significant impact of all the variables. Our main finding includes that Inflation rate stimulate unemployment positively and GDP growth rate and Exchange rate has negative impact on unemployment.
\end{abstract}

Keywords: Unemployment rate, GDP growth rate, Exchange rate, Inflation rate.

\section{Introduction:}

Unemployment is one of the major problems in almost all the countries of the world. It has been the most consistent problem which is facing by all industrially advanced as well as poor countries. Unemployment is defined as the condition of having no job or being out of work or proportion of people which are able to work and actively searching jobs but they are unable to find it. Some of the very common causes of unemployment in Bangladesh and other developing economies are the technological changes, contribution of women in labor force, demographic structure, economic conditions, production of electricity (especially in Bangladesh), immigration from rural area's towards towns and cities. A decrease in the growth of the economies because of the economic recession of October 2008 is a major reason of increasing rate of unemployment for both developed and developing countries. According to theory, there is a positive relation between employment and the economic growth of countries.

Economic growth is a vital factor that affects the unemployment. Theoretically a positive relation should exist among growth and employment or negative with unemployment. The economic theory, which converse on the subject of the relationship between unemployment and the economic growth is named as Okun's law. He studied the trade off among the real GNP and the unemployment. According to the theory there is an inverse relation between growth and the unemployment. The relationship between unemployment and the inflation is termed as Philips curve in the economic theory and was developed in 1958 by A. W. H. Philip. He discovered positive relationship between the two variables. Individually, inflation and unemployment both have negative effects on the individuals. With the globalization and open trades, exchange rate has started playing a vital role in the economy which has a direct effect on the unemployment level in a country. With devaluation, exports tend to boost and as a result expenditure on imports are reduced. By this, inflow of foreign currency is enhanced economies move towards growth and consequently the rate of unemployment declines.

\section{Objectives of this study:}

In Bangladesh GDP growth rate, exchange rate and inflation rate are the most important economic variable to determine unemployment. The key objectives of this study are:

- To check out the impact of GDP growth rate on unemployment.

- To analyze the effect of exchange rate on unemployment.

- To check out the impact of inflation rate on unemployment.

\section{Literature Review:}

On the basis of information, collected from the existing articles, an attempt has been made to make an overview of the existing literature. 
Tunah (2010) studied that macroeconomic variable which cause of unemployment for Turkey. Quarterly data from 2000 to 2008 is used as the sample data for the study. Augmented Dickey Fuller test (ADF), Phillip-Perron test, Johanse's cointegration and granger causality techniques were used for analysis. The results showed that there is a significant impact of real GDO, consumer price index and previous unemployment rate on the unemployment rate. Whereas real effective exchange rate has no impact on the unemployment.

Ozturk L. \& Akhtar.I. (2009) took an comprehensive approach to unemployment by using VAR of "Variance Decomposition and Impulse response function analysis". He was interested in studying interrelationship among Foreign Direct investment, Export, Gross Domestic product and unemployment in Turkey for the period of 2000-07. They found only two counteracting vectors in the system, showing long run relationship. They concluded that foreign direct investment did not lead to reduce unemployment in Turkey. GDP is positively affected by variations in exports but is insignificant. So they did not found any evidence of export led growth in Turkey. Again, Variations in DGP was no attached with reduction of unemployment.

Marika Karanassou.et.al (2007) analyzed labor market dynamically to find relationship between capital stock and unemployment. They used indirect transmission channels of the effects of capital stock for estimating single equation unemployment model. The major variables they used were interest rates and investment ratios. They introduced different approaches especially by direct estimation of the model of "Employment theory of Chain response" for the effects of capital stock on labor market. They concluded that capital stock is the key determinant of unemployment.

El-Agrody et al. (2010) examined the economic study of unemployment and its impact on the GDP for Egypt. Data was collected from year 1994 to 2004. Simple and multiple linear regression analysis were applied. Variables used in the study were privatization, population, consumption expenditure, interest rates, exchange rates, technology, agricultural domestic product, real wage rates and agricultural investment. The results showed that there is a significant positive impact of national unemployment, national investment, exchange rate and average per capita share of GDP on the volume of GDP. The results also highlighted privatization and increasing population as the main reasons of increasing unemployment. They recommended that privatization policies need to be revised and to reduce interest rates in order to lowering the agricultural unemployment.

Kupets. O.V (2005) studied determinants of unemployment in Ukraine between 1997 \& 2003. He used Ukrainian Longitudinal Monitoring Survey 2003, to investigate an individual conditional probability about leaving unemployed to employ. Effects of unemployment benefits on unemployment were not confirmed. Again, Multivariate analysis suggested that long term unemployment reduction policies should focus more on less educated \& older workers and residents of rural areas.

Mark C. Foley (1997), Russian people's longitudinal survey for studying determinants of unemployment in early stages of economic transition in Russia. He used a discrete-time waiting model along with competing risk and heterogeneity models. He concluded that married women experience longer unemployment period than married man. Older worker face higher unemployment period as compared to younger worker. Persons with lower education were forced to have longer unemployment spell.

Pallis (2006) studied the relationship between inflation and unemployment in new European Union member states. The data used in this analysis is annual that covered the period from 1994 to 2005, taken from European commission 2004 referred to the new 10EU member states. The three variables used are "the price deflator of GDP at market prices, nominal compensation per employee and total employment rate (\%). Non-linear least square method of estimations and E-views techniques are used. This paper concludes that the application of common policies across economy may be questionable because of the different effect of these policies on inflation and unemployment.

Elameskov.et.al (1998) focused on relationship and taxation in OCED countries for the period of 1983-1994. He used Hausman specification test \& concluded that impact of taxation on unemployment is positive and exogenous in short run where as in long run relationships are simultaneously determined. Main conclusion is taxation as a major determinant of unemployment in long run.

Aleksander.et.al (2009) focused on studying long run relationships among money supply, interest rate and unemployment. They concluded that these variables are positively related at low frequencies. They developed such a framework where money and unemployment were modeled by using micro details based on "search and bargaining theory". They provided a unified theory for analysis of labors and goods markets. As people hold a sizable amount in unemployment so the use of monetary theory can be on basis of search and bargaining or may an alternative ad hoc plan.

Shu-Chen Chang.(2006) applied VAR method of variance decomposition and impulse response function analysis for studying relationship among economic growth, trade foreign direct investment (FDI) and unemployment in Taiwan. The result showed that export and economic growth effect FDI inflow positively however export expansion has negative impact on FDI outflow. Study confirmed no relationship between FDI and unemployment where as negative relationship between unemployment and economic growth was obvious and confirmed. 
Though a lot of work has been done on relationship between unemployment and other set of macroeconomic variables but less attention is paid to determinants of unemployment i.e. what are the major determinants of unemployment? This paper proceeds to employ simple econometrics technique of regression analysis for analyzing determinants of unemployment based on evidence from Bangladesh economy.

Research Methodology:

We have estimated simple single equation linear regression model (SELRM) for analysis of determinants of unemployment in Bangladesh economy. Simple specification of SELRM is given bellow:

$U R=\beta_{0}+\beta_{1} G D P+\beta_{2} E X R+\beta_{3} I N F+U_{i}$

Where,

UR = Unemployment rate,

$\mathrm{GDP}=\mathrm{GDP}$ growth rate,

$\mathrm{EXR}=$ Exchange rate,

$\mathrm{INF}=$ Inflation rate.

$\mathrm{U}_{\mathrm{i}}=$ Error term.

Data on each variable have been taken from the world economic outlook, www.mole.gov.bd. and CIA world factbook for the period of 2000-2001. Model is estimated using OLS techniques and significance of results have been checked by using usual t-test. Because of this study uses time series data, so unit root test and cointegration should be checked out. But the sample size is not large enough to test cointegration as well as unit root test. So unit root test and cointegration test are not considered in this study.

\section{Empirical Results:}

Based on data for the period of 2000-2011, by using an econometric program SPSS (16.0) the empirical result of estimated SELRM is presented in the following table:

Table No-1: Regression Results

\begin{tabular}{|c|c|c|c|c|c|c|}
\hline \multirow{2}{*}{\multicolumn{2}{|c|}{ Model }} & \multicolumn{2}{|c|}{ Unstandardiked coeficients } & \multirow{2}{*}{$\begin{array}{l}\text { Standardized } \\
\text { Coefficients } \\
\text { Geta }\end{array}$} & \multirow[b]{2}{*}{$\mathrm{t}$} & \multirow[b]{2}{*}{ Sig. } \\
\hline & & E & Sto. Error & & & \\
\hline \multirow[t]{4}{*}{1} & (Constant) & 253.210 & 35.922 & & 7.049 & . \\
\hline & 6DP & -11.624 & 4.680 & -.420 & -2.484 & .038 \\
\hline & EXR & -3.096 & .545 & -1.266 & -5.676 & .000 \\
\hline & IINF & 4.989 & 1.686 & .764 & 2.959 & .018 \\
\hline
\end{tabular}

a. Dependent Variable: UNR

Source: Buthors" Estiruations

From the table- 1 it can be said that the estimated coefficients have all expected sign. i.e. GDP growth rate and exchange rate have significant negative impact on rate of unemployment and inflation rate has a significant positive impact in Bangladesh. The t-value of the coefficient of GDP growth rate, exchange rate and inflation rate are $-11.624,-3.096$ and 4.989 , which are statistically significant. If all other variables remain constant the estimated regression equation is as follows:

$\mathrm{UR}=253.210-11.624 \mathrm{GDP}-3.096 \mathrm{EXR}+4.989 \mathrm{INF}+\mathrm{U}_{\mathrm{i}}$

Table-2: Model Summary

\begin{tabular}{|c|c|c|c|c|c|c|c|c|c|c|}
\hline \multirow[b]{2}{*}{ Wodel } & \multirow[b]{2}{*}{$\mathrm{F}$} & \multirow{2}{*}{$\begin{array}{l}\mathrm{R} \\
\text { Square }\end{array}$} & \multirow{2}{*}{$\begin{array}{l}\text { Adjusted } \\
\text { R } \\
\text { Square }\end{array}$} & \multirow{2}{*}{$\begin{array}{l}\text { Std. Error } \\
\text { of } \\
\text { Estimate }\end{array}$} & \multicolumn{5}{|c|}{ Change Statistics } & \multirow[b]{2}{*}{$\begin{array}{l}\text { Durbin- } \\
\text { Wuatson }\end{array}$} \\
\hline & & & & & $\begin{array}{l}\text { R Square } \\
\text { Change }\end{array}$ & $\begin{array}{l}\text { F } \\
\text { Change }\end{array}$ & df1 & $\mathrm{df2}$ & Sig.r $F$ & \\
\hline 1 & .944 & 890 & .849 & 7.06190 & .890 & 21.633 & 3 & 8 & . & 1.658 \\
\hline
\end{tabular}

a. Fredictors: (Constant), INF, GDF, EXF

b. Dependent Variable: UR

Source: Author's estimations

From the table-2 it can be said that the value of R-Square is 0.89 , which indicate very well fit to data. That is almost $89 \%$ of the variation in the unemployment rate in Bangladesh is explained by GDP growth rate, exchange rate and inflation rate. The value of $d$-statistic is 1.658 . For $n=12$ and $k=3$ Durbin-Watson statistic $d_{L}=0.658$ and $d_{U}=1.864$ at $5 \%$ level of significance. Since $d<d_{U}$, so there is statistically significant evidence of positive first order serial autocorrelation. 
Table-3: ANOWA

\begin{tabular}{|c|c|c|c|c|c|c|}
\hline \multicolumn{2}{|c|}{ Model } & $\begin{array}{l}\text { Sum } \\
\text { Squares }\end{array}$ & iff & Mean Square & $F$ & Sig. \\
\hline \multirow[t]{3}{*}{1} & Fegression & 3236.585 & 3 & 1078.862 & 21.633 & .000 \\
\hline & Residual & 398.964 & 8 & 49.870 & & \\
\hline & Total & 3635.549 & 11 & & & \\
\hline
\end{tabular}

a. Predictors: (Constant), INF, GDP, EXR

b. Dependent Variable: UR:

Source: Author's estirnations

The F-value is 21.633 while the critical values for $\mathrm{F}$ are 4.07 at $5 \%$ and 7.59 at $1 \%$ level of significance. So Fvalue 21.633 indicates that $R^{2}$ is statistically significant. That is the estimated equation is significant. $\mathrm{P}=0.00$, which shows impact of all independent variable on dependent variable is significant. So we can say our model us overall significant.

\section{Recommendation:}

- $\quad$ The policy makers need to improve the distribution of income in Bangladesh to shift the impact of growth towards the betterment of the employment rate.

- We need to have proper utilization of foreign investment to improve growth and reduce unemployment.

- $\quad$ To avoid the increasing rate of unemployment situation, training opportunities need to be developed in order to develop skills of old and new workers of organizations to adopt changes of the environment.

- Government need to create employment opportunities for both educated and uneducated people.

- Labor intensive strategies are needed for the poor people in rural and urban areas so that they can participate in the growth of the economy.

Due to limited time and the resources, data used is very limited. Further research can be done by using age, gender, qualification, sector, wages etc. as variables to have a broad view towards unemployment and the reasons of unemployment.

\section{Conclusion:}

Unemployment has been very consistent problem and remains difficult to manage in many countries. Unemployment can be viewed from different dimensions but the present paper focus on the determinants of unemployment. Our finding reveals that inflation rate stimulates unemployment positively and GDP growth and exchange rate has negative impact on unemployment. We observed trade-off between unemployment and inflation in Bangladesh economy but more research is needed to check it whether is short run trade-off or long run one.

\section{References:}

Tunah, H. (2010). "The Analysis of Unemployment in Turkey: Some Empirical Evidence Using Cointegration Test”. European Journal of Social Sciences, 18 (1): 18-38.

Latif Ozturk and Ismail Aktar. (2009). "Can Unemployment be Cured by Economic Growth and Foreign Direct Investment in Turkey?" International Research Journal of Finance and Economics. 27: 1450-2887.

Mrika Karanassou, Hector Sala and Pablo F. Salvador (2007). "Capital Accumulation and Unemployment: New Insights on The Nordic Experience". Economic Review. 90 (5): 1223-1322.

El-Algrody, N. M., Othman, A. Z., \& Hasan, M. B. D. (2010). "Economic Study of Unemployment in Egypt and Impact on GDP". Nature and Science. 8 (10): 102-111.

Kupets O. V. (2005). "Determinants of Unemployment Duration in Ukraine-Moscow: EERC". Economics Education and ResaerchConsortium. Working paper series.

ISSN: $1561-2422$.

Mark C. Foley. (1997). "Dterminants of Unemployment Duration in Russia”. Center Discussion Paper No. 779. Economic Growth Center.

Pallis, D. (2006). “The Trade-off Between inflation and Unemployment in New European Union Member States. International Research Journal of Finance and Economics (1): 81-97.

Elmeskov, J., J. P. Martin and S. Scarpetta (1998). "Unemployment and Labor Market Rigidities in OECD Countries: The Impact of Taxes". Swedish Economic Policy Review 5 (2): 207-258. 
Aleksander Berentsen, Guido Menzio and Randall Wright (2009). "Inflation and unemployment in The Long Run". Federal Publications.

www.worldbank.org

www.mole.gov.bd

www.bb.org.bd 